ISSN 2078-6077.

Наукові зошити історичного факультету Львівського університету. 2020. Випуск 21. С. 289-304

Proceedings of History Faculty of Lviv University. 2020. Issue 21. P. 289-304

УДК [78.036(477.83-25):784.071.2 С.Федак]“188/1937”

\title{
СТЕПАН ФЕДАК: ШТРИХИ ДО ПОРТРЕТА НА ТЛІ УКРАЇНСЬКОЇ МУЗИЧНОЇ КУЛЬТУРИ ЛЬВОВА
}

\author{
Наталія КОБРИН \\ Львівська середня спеціалізована \\ музична школа-інтернат імені Соломії Крушельницької \\ вул. Зелена, 10, Львів, 79005, Україна \\ e-mail: kobryn.natalya@gmail.com
}

Степан Федак (1861-1937) - відомий у першій половині ХХ ст. український адвокат та один із перших диригентів хорового товариства “Львівський Боян”. Його діяльність у сфері національної музичної культури дуже високо оцінювали сучасники. На тлі характеристики основних явищ національної музичної культури межі XIX-XX ст. розглянуто формування мистецьких зацікавлень С. Федака та основні напрями його музично-громадської праці. За матеріялами періодичної преси проаналізовано свідчення про диригентську дільність С. Федака у “Львівському Бояні”, проведені під його керівництвом концерти, а також визначено орієнтовний перелік виконаних творів.

Ключові слова: музична культура галицьких українців, “Львівський Боян”, концерти, диригент, С. Федак.

3 нагоди сорокаліття утворення хорового товариства “Львівський Боян” одного $з$ провідних осередків плекання національної музичної культури в першій половині XX ст., галицький щоденник “Діло” опублікував історичну розвідку, де вперше узагальнено діяльність товариства від його початків до 30 -х рp. XX ст. Автор цієї статті - визначна постать галицько-української музики та діяльний член “Львівського Бояну” С. Людкевич, перераховуючи найпочесніших, на його думку, “бояністів", поруч з іменами засновника і першого голови товариства В. Шухевича, композитора і першого диригента “Бояна" А. Вахнянина та інших “найбільш заслужених діячів"2 назвав і д-ра С. Федака. Висока оцінка заслуг відомого в Галичині адвоката на ниві музичної, зокрема хорової, культури з уст знаменитого композитора мала свою передісторію. Серед ранніх творів С. Людкевича - також свого часу диригента товариства, значиться написана орієнтовно 1900 р. "Кантата на честь Ст. Федака"з, яка прозвучала 14 січня 1901 р. на ювілейному вечорі з нагоди його 40-ліття ${ }^{4}$.

\footnotetext{
${ }^{1}$ Ювілей 40-ліття утворення “Львівського Бояна” відзначався у Львові з деяким запізненням у 1932 р. Див. Борис Кудрик, “Концерт 3 нагоди 40-ліття «Львівського Бояна»”, Діло, ч. 58, (1932): 3-4.

${ }^{2}$ Станіслав Людкевич, “У сорокліття «Львівського Бояна»” (1891-1931), Діло, ч. 52, (1932): 2.

${ }^{3}$ У нотографії С. Людкевича ця кантата, на жаль, значиться із ремаркою "музика не збереглася". Див. Зеновія Штундер, Станіслав Людкевич. Життя і творчість, у 2 т., Т. 1 (18791939). (Львів, 2005), 599.

${ }^{4}$ М. В., [Львоิвскій Боянъ], Д 
ISSN 2078-6077. Наукові зошити історичного факультету Львівського університету. 2020. Випуск 21. Proceedings of History Faculty of Lviv University. 2020. Issue 21.

У сучасній науковій літературі в контексті досліджень історії українських музичних товариств Галичини прізвище С. Федака - одного із засновників “Львівського Бояну”, заступника голови товариства, члена Виділу і диригента згадується лише епізодично. При тому навіть у цих нечисленних поданих фактах привертають увагу окремі розбіжності, наприклад, щодо точного часу i тривалости перебування С. Федака головним диригентом “Бояну” у Львові 1898 чи/i 1894 p. ${ }^{5}$, майже відсутній аналіз проведених ним концертів товариства і т. ін. Музична складова діяльности С. Федака - це маловідомі чи невідомі епізоди його життєпису, однак вони є цікавими сторінками формування українських музичних інституцій у Галичині та національно-культурного відродження, студії над якими збагатять українську історико-краєзнавчу науку.

Українські музичні товариства Галичини постали як невід’ємна складова національної самоорганізації українців у кінці XIX - на початку XX ст. Їх рушійною силою була сформована на той час генерація музикантів-аматорів, активних діячів українського руху і культурного відродження загалом. Соціологічнопрофесійну характеристику тієї генерації першим сформулював О. Бережницький - правник і скрипаль, музичний критик, член “Львівського Бояну”, виокремлюючи три особливо заангажовані в аматорське музикування суспільні верстви - “священики, урядники, професори”". У 1934 р. - в рік організації першої в Галичині української спілки фахових музикантів Союзу Українських Професійних Музик (СУПроМ-у), цей висновок підтвердив піяніст Т. Шухевич (син відомого етнографа і першого голови “Львівського Бояну” В. Шухевича). У своїй статті він назвав професії, представники яких, на його думку, традиційно найбільше цікавилися музичним мистецтвом, - лікарі та правники, уточнюючи, що в Галичині “одне з перших місць займає священичий стан” .

Період найактивнішої організаційної, виконавської і творчої діяльности аматорської верстви галицько-українських музикантів охоплює другу половину XIX - початок XX ст., сягнувши вершини в утворенні мережі національних хорових товариств “Боянів". Як твердив С. Людкевич, ця назва для означення українських хорових товариств Галичини могла бути запозиченою із Наддніпрянщини ${ }^{8}$. Однак слід зауважити, що декілька років до утворення “Львівського Бояну" цю ж назву використав о. В. Матюк- упорядник однойменного збірника українських творів галицьких композиторів для чоловічого хору (1884). Саме “бояністи”, як називали сучасники найактивніших прихильників і діячів товариства, на межі XIX-XX ст., сформували провідну верству українських галицьких музикантів. Мистецький світогляд, музично-естетичні

\footnotetext{
5 Лєшек Мазепа і Тереза Мазепа, Шлях до Музичної Академії у Львові, у 2 т. Т. 1. (Від доби міських музикантів до Консерваторії [поч. XV стр. - до 1939 р.]. (Львів, 2003), 72; Лідія Ханик, Історія хорового товариства "Львівський Боян". (Львів, 1999), 21-27.

${ }^{6}$ Олесь Бережницький “Наші музики”, Артистичний Вістник, зош. 9/10, (1905): 124.

${ }^{7}$ Тарас Шухевич, “Чи музичне виховання молоді потрібне?”, Діло, ч. 312, (1934): 2.

${ }^{8}$ Станіслав Людкевич, “У сорокліття «Львівського Бояна»” (1891-1931), Діло, ч. 51, (1932): 2.
} 
пріоритети та форми діяльности цієї генерації виразно засвідчують витоки, особливості й напрями розвитку української музичної культури у другій половині XIX - на початку XX ст. ${ }^{9}$

Музичні зацікавлення представників цієї музично-аматорської верстви формувалися в атмосфері національного культурного відродження i любительського музикування. Базові основи музичної освіти в тогочасній Галичині давали змогу здобути переважно академічні хори, розповсюджені в різного типу школах, гімназіях, бурсах і семінаріях. У другій половини XIX ст. ці розмаїті шкільні хори часто існували завдяки виразній перевазі українців. С. Людкевич (композитор, який до середини 20 -х pp. XX ст. викладав українську та латинську мови у Перемишльській, згодом - Львівській гімназіях ${ }^{10}$ ) доволі розлого описав цю особливість галицької культури. Як музикант, він також почав свій шлях у колі учнів Ярославської гімназії з ії двома хорами (один складався лише $з$ українців) та інструментальною капелою. Можна припустити, що ситуація, яку описав С. Людкевич, була доволі типовою: “Хори в тих гімназіях, де українців третина або й четвертина, заступлені є в більшости або й майже виключно учениками українцями, що дуже рано показують велику охоту до співу, а пізніше й до “дириговання". Учити співу в гімназії, звісно, має якийсь музикальний профеcop, nota bene, коли найдеться такий, коли ж ні, то частіш усього виходить на диригента, особливо в гімназіях Східної Галичини, якийсь музикальний, похопний до дириговання співак-ученик, додавати злишньо, українець [...]. Маю зовсім певні, відомі дані, що в більшій половині гімназій Східної Галичини хор з гімназіяльних учеників полишається ученикові, усе українцеві"11.

Із власне українських інституцій, що давали можливість здобути музичну освіту, у Львові функціонували Греко-Католицька Духовна Семінарія і бурса Ставропігійського Інституту - два перші і традиційні на той період осередки розвитку національної культури. Зокрема, зі Ставропігією та ії хором, що був утворений 1831 р., пов'язана діяльність багатьох тогочасних галицькоукраїнських музикантів і композиторів, серед яких о. М. Вербицький (автор національного гимну), о. П. Бажанський, о. Й. Левицький, Я. Неронович, М. Рудковський ${ }^{12}$.

\footnotetext{
${ }^{9}$ Докладно див. Наталія Кобрин, “Музика як складова громадської праці галицьких українців на межі XIX-XX ст. (на прикладі діяльності Андрія Чайковського)”, Визначні постаті Украӥни: Андрій Чайковський та Теофіл Окуневський”: Збірник наукових праць, присвячених 150-річчю від дня народження Андрія Чайковського (2007) та Теофіла Окуневського (2008). Гол. ред та упор. Б. Якимович за участю Н. Кобрин, В. і Р. Мельників, О. Седляра. (Львів: Афіша, 2010), 78-84 (серія “Визначні українці”, ч. 2)

10 Зеновія Штундер, Станіслав Людкевич. Життя і творчість, у 2 т., Т. 1 (1879-1939). (Львів, 2005), 209.

${ }^{11}$ Станіслав Людкевич, "Наші співаки і народна справа”, у книзі Дослідження, статmі, рецензї, виступи, у 2 т., упор. і ред. 3. Штундер, т. 2. (Львів, 2000), 352-353.

12 Зиновій Лисько, Піонери музичного мистецтва в Галичині”, упор. В. Сивохіп. (Львів, Нью-Йорк, 1994)., 43 с.
} 
ISSN 2078-6077. Наукові зошити історичного факультету Львівського університету. 2020. Випуск 21. Proceedings of History Faculty of Lviv University. 2020. Issue 21.

У короткій біографії С. Федака, надрукованій 1937 р., стверджувалося, що “завдяки незвичайно гарному сопрановому голосові прийняли Степана до бурси Ставропігійського Інституту" 13. Час його перебування у Ставропігії співпав із періодом діяльности в ній о. П. Бажанського - композитора, диригента i теоретика, помітної постаті на ниві галицько-української культури 3 дещо суперечливими та своєрідними мистецькими поглядами. П. Бажанський від 1865 р. до середини 80-х рр. керував хором Ставропігійської бурси ${ }^{14}$. Як твердив у своїх статтях В. Витвицький, покликаючись на думку Ф. Колесси, “Бажанський чи не найкраще з усіх галицьких українських музик звернув увагу на народні пісні, їх типові признаки в мелодії і ритміці, прийнявся за збираня і наукове прослідження багатого пісенного матеріялу та познайомився $з$ дотичною літературою" 15 . Перебування в бурсі Ставропігійського Інституту та його музична атмосфера мали, ймовірно, вагомий вплив на формування музичних зацікавлень С. Федака, який згодом, у студентські роки, був і сам диригентом академічного хору ${ }^{16}$.

Доволі розповсюдженим явищем другої половини XIX ст. була участь українців в інших національних музичних товариствах Галичини i, зокрема, Львова. Наприклад, прізвища українців - Мартина Барвінського (предка композитора В. Барвінського), Михайла Левицького та композитора о. І. Лаврівського знаходимо у списках Галицького Музичного Товариства $(\text { ГМТ })^{17}$. Однак чи не найбільша кількість українців зафіксована у 80 -х рp. ХІХ ст. у польському хоровому товаристві “Лютня”, що як чоловічий хор відокремилося у 1880-1881 рр. від ГМТ ${ }^{18}$, згодом трансформувалось у мішаний хор. 3 огляду на нечисленність і нестабільність тогочасних українських музичних інституцій (хорове товариство “Торбан”, що його заснував А. Вахнянин 1870 р., функціювало лише рік), чимало галицьких українців, аматорів хорового руху свій мистецький і диригентський досвід здобули саме в “Лютні”. У іiі складі співали Є. Барвінська, В. Будзиновський, А. Вахнянин, Г. Вітошинський, О. Мишуга, о. О. Нижанківський, Р. Прокопович, В. Шухевич, а також С. Федак та ін. Крім того, В. Шухевич 1889 р. був обраний у Виділ товариства ${ }^{19}$, А. Вахнянин і С. Федак ${ }^{20}$ у різні періоди

${ }^{13}$ Д-р Степан Федак, ч. 6, Діло. (1937): 3.

${ }^{14}$ Борис Кудрик, Огляд історії украӥнської иерковної музики. (Львів: Інститут українознавства ім. І. Крип’якевича НАН України, 1995), 96.

${ }^{15}$ Василь Витвицький, “Століття уродин двох українських музик (Пам’яті П. Бажанського й С. Воробкевича)”, Новий Час, ч. 105, (1936): 2

${ }_{16}^{16}$ Д-р Степан Федак, ч. 6, Діло. (1937): 3.

${ }^{17}$ Справа про організацію музичного товариства, Центральний державний історичний архів (далі - ЦДІА) України, м. Львів, ф. 146, оп. 4, спр. 665, арк. 21; Звіт дирекції ГМТ за 1865 р., Державний Архів Львівської області (далі - ДАЛО), ф. 3, оп. 1, спр. 2384.

18 Лєшек Мазепа і Тереза Мазепа, Шлях до Музичної Академії у Львові, у 2 т. Т. 1. (Від доби міських музикантів до Консерваторії [поч. XV стр. - до 1939 р.]. (Львів, 2003), 65.

${ }^{19}$ Володимир Шухевич: Біобібліографічний покажчик у 2 ч., ч. 1, уклад.: М. Гордій, Б. Геляс; вступ. ст. Р. Кирчіва. (Львів: Вид. центр ЛНУ ім. Івана Франка, 2004), 90.

${ }^{20}$ Музична діяльність С. Федака у польському хоровому товаристві “Лютня” у 80-ті pp. XIX ст., як і загалом історія розвитку цього товариства потребує окремих докладних студій. 
значилися диригентами хору ${ }^{21}$. Імовірно, саме це й було однією з причин участи “Лютні” - польського хорового товариства, у шевченківських концертах 80-х рр.: хор виконував твори українських композиторів - о. М. Вербицького, о. І. Лаврівського, А. Вахнянина, М. Лисенка. Про кількість і вагу українців у хорі “Лютня” свідчить і згадка про якийсь конфлікт у колах львівських аматорів музики, що виник унаслідок утворення хорового товариства “Боян”. Про цей інцидент коротко згадав В. Шухевич на Перших загальних зборах товариства: "Перед оิдчитаньемъ статутоิвъ полагодивъ проф. Шухевичъ въ умотивованоิй промов t непорозумънье, а именно: мовъ-бы то черезъ ново-заложене товариство Боянъ мусиิло розпасти ся товариство “Лютня"22.

Музична діяльність С. Федака протягом багатьох років пов'язана 3 “Львівським Бояном", де він, як характеризував згодом автор некрологу в часописі “Життя і Знання”, “до останку співав у його хорі й виступав на його концертах. 3 цього погляду міг бути зразком для всіх: він ніколи не пропустив ні одної проби" "23. Протягом першого десятиліття діяльности “Львівського Бояна" С. Федак, як один із засновників товариства ${ }^{24}$ виконував різні обов'язки ${ }^{25}$ :

- його обирали заступником голови Виділу товариства (головою “Львівського Бояна" у той час був В. Шухевич), очевидно, протягом $1891 \mathrm{p.}^{26}$ - весни $1894 \mathrm{p.}^{27}$, листопада 1894 p. ${ }^{28}$ - осені 1896 p. $^{29}$;

- С. Федак був головним диригентом “Львівського Бояна” в 1894 p. (протягом понад пів року після переїзду А. Вахнянина до Відня, де він виконував обов'язки посла до Державної Ради $\left.{ }^{30}\right)$, впродовж $1896^{31}-1901$ pp. ${ }^{32}$, будучи обраним з огляду на можливий виїзд зі Львова о. О. Нижанківського ${ }^{33}$ (диригента товариства в 1895 - 1896 рр.) і 1903 p. ${ }^{34}$;

${ }^{21}$ Лєшек Мазепа і Тереза Мазепа, Шлях до Музичної Академії у Львові, у 2 m. T. 1. (Від доби міських музикантів до Консерваторії [поч. XV ст. - до 1939 р.]. (Львів, 2003), 69.

22 “Першы загальны зборы руского споิвного товариства «Боянъ»”, Дкло, ч. 20 (1891): 3.

23 “Тi, що від нас відійшли [Др. Степан Федак]”, Життя і Знання, ч. 2(113), (1937): 64.

${ }^{24}$ Статути товариств Галичини, ЦДІА України у м. Львові, ф. 362, оп. 1, спр. 196, арк. 18.

${ }^{25}$ Наведені нижче дані можуть бути неповними.

26 “Першы загальны зборы руского споิвного товариства «Боянъ»", Дс

ло, ч. 20 (1891): 3.

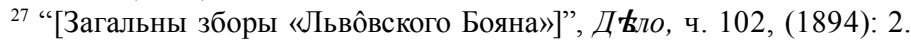

28 “Рухъ въ рускихъ товариствахъ”, Д

29 “Ювилейны загальны зборы товариства «Просвьта»”, Джло. ч. 17, (1894): 1.

30 “[Загальны зборы «Львоิвского Бояна»]”, Д

${ }^{31}$ Степан Федакъ і Володимир Шухевичъ “Воิдозва и запросины до споิволюбныхъ русиноิвъ”, Д $\mathbf{k} л о$, ч. 221, (1896): 3; “Рухъ въ рускихъ товариствахъ [Загальны зборы тов.«Львоิвскій Боянъ»]”, Д中ло, ч. 260, (1896): 3.

32 “Зъ Львівского Бояна”, Діло, ч. 260/261, (1901): 3.

33 “[О. Остапа Нижанковского...]”, Д длло, ч. 139, (1896): 1-2.

${ }^{34}$ Михайло Волошин, “Львівський Боян”, Альманах Музичний. Літературна часть першого ілюстрованого калєндаря музичного на рік 1904. Зложив і впорядкував Р. Зарицкий. (Львів, 1904), 105-111. 
ISSN 2078-6077. Наукові зошити історичного факультету Львівського університету. 2020. Випуск 21. Proceedings of History Faculty of Lviv University. 2020. Issue 21.

- у 1901 р. на з'їзді галицьких “Боянів”, що був проурочений до 10-ліття заснування товариства у Львові, С. Федак, поруч із В. Шухевичем, о. О. Нижанківським, Я. Вітошинським, Ф. Колессою і С. Людкевичем, був обраний членом комітету для укладення статуту “Союза Боянів" 35 ;

- ім'я С. Федака значиться і серед засновників Союзу українських співацьких і музичних товариств у 1903 р. ${ }^{36}$ (на примірнику статуту 1921 p. вказані також імена В. Шухевича, Р. Ганінчака, О. Бережницького і Я. Вітошинського); він і очолював це товариство в 1904 p. ${ }^{37}$;

- С. Федак увійшов до комісії Музичного товариства ім. М. Лисенка щодо спорудження будинку товариства, яку обрали загальні збори 18 липня $1913 \mathrm{p.}^{38}$

Диригентська діяльність у “Львівському Бояні” - маловідома сторінка не лише життєпису адвоката, але й в історії товариства. Досвід роботи в академічному хорі гімназії та хоровому товаристві “Лютня” були важливі, однак, очевидно, не єдині мотиви, щоб його обрали диригентом хору. Цікавий аргумент подав на загальних зборах “Львівського Бояна" в 1896 р. В. Шухевич, прогнозуючи кращі можливості розвитку товариства у майбутньому: йшла мова про власне приміщення для репетицій чоловічого хору і школи співу, а також про те, що “упрошеный на будучого дірігента д-ръ Стефанъ Федакъ живе постойно у Львов и иымъ самымъ зможе уложити собъ програму своихь праць (підкреслення наше - H. K.)"з39. Слід зазначити, що його попередниками були А. Вахнянин - композитор, при тому активно залучений до суспільно-політичного pyху 90-х рр. ХІХ ст., та о. О. Нижанківський - відомий диригент і композитор, що $з$ причини матеріяльних труднощів змушений був виїхати зі Львова. Це, ймовірно, і пояснювало дещо нестабільну діяльність хору та скасування окремих концертів з огляду на відсутність у відповідний період часу головного диригента, про що твердив В. Шухевич на згаданих зборах.

Заслуговують на увагу ще й ті серед галицько-українських музикантів, які починали свою мистецьку кар'єру композитора, диригента, музичногромадського діяча поруч із С. Федаком, передовсім, як заступники головного диригента “Львівського Бояну”. Серед них - Ф. Колесса (фольклорист і композитор), що обирався заступником диригента товариства на 1893, 1895 1898 рр., та С. Людкевич (один із провідних українських музикантів першої

35 “Рухъ в рускихъ товариствахъ. Зъ ззд «Бояноิвъ»”, Д $\mathbf{k} о$, ч.260/261, (1901): 3 .

${ }_{36}$ Устав музичного товариства імені Миколи Лисенка. Третє видання. (Львів: накладом товариства, 1921), 2. Львівська національна наукова бібліотека (далі - ЛННБ) ім. В. Стефаника, відділ рукописів, ф. 163, п. 50, арк. 36.

37 Лєшек Мазепа і Тереза Мазепа, Шлях до Музичної Академії у Львові, у 2 т. Т. 1. (Від доби міських музикантів до Консерваторії [поч. XV стр. - до 1939 р.]. (Львів, 2003), 74.

${ }^{38}$ Звіт з будови власного дому Муз. Товариства ім. Миколи Лисенка зладжений на загальні збори Товариства дня 26 мая 1917. (Львів: Накладом Муз. Товариства, [1917]), 4.

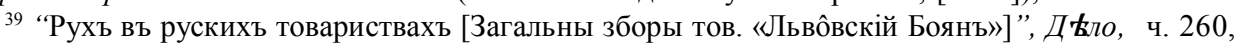
(1896): 3 . 
половини XX ст.) - впродовж 1899-1901 pp..$^{40}$ Із жінок - диригенток хору, виділяються постаті Є. Барвінської-Любович та Г. Шухевич (обидві значаться серед засновників товариства).

Найактивніший період диригентської праці С. Федака збігся із першим (раннім) етапом функціонування “Львівського Бояна”, який згодом С. Людкевич у своїх статтях окреслив 1891-1903 рр. і охарактеризував як такий, що “пройшов під знаком збирання бібліотеки для хорового репертуару і взагалі, так би сказати, під знаком розмаху крил та шукання напрямних розвою"41 . Товариство покликане було, передовсім, забезпечувати музичну частину розмаїтих національноманіфестаційних урочистостей, святкувань та концертів, зокрема i Шевченківських вечорів - однієї з головних форм тогочасного українського концертного життя. Всі зазначені національні культурно-музичні дійства організовувалися за співучасті провідних українських установ. Зокрема, програми Шевченківських концертів на початку 90-х рр. XIX ст. традиційно декларувалися під егідою Народної Ради, "Просвіти”, Товариства імени Шевченка, “Руської Бесіди”, Руського Товариства Педагогічного, товариства ремісників “Зоря”, i “Львівського Бояну"42. У процесі зростаючої диференціяції національного суспільного життя і збагачення форм музичної культури чимало українських організацій влаштовували власні шевченківські святкування, однак на межі XIXXX ст. традиційно й тісно співпрацювали “Львівський Боян” та “Просвіта".

Упродовж зазначеного етапу “Львівський Боян”, зазвичай, щороку готував від двох до п'яти різних концертів, а також - виїжджав із концертними програмами в інші регіони Галичини (т. зв. мандрівні “дванадцятки” i “шістнадцятки”, в яких брали участь переважно студенти). Ще одна вагома ознака концертної діяльности товариства у той час - блискучі солісти, згодом світової слави виконавці, які в 90-х рр. XIX ст. майже щорічно брали участь у концертах “Львівського Бояна” - С. Крушельницька й О. Мишуга.

Дуже складно точно окреслити перелік концертів та урочистостей, у яких С. Федак брав участь як диригент (зрештою як і його диригентський репертуар). Рецензенти періодичних видань далеко не завжди точно вказували прізвища диригентів кожного конкретного концерту: ними могли бути й автори прем'єрних творів, і заступник головного диригента товариства. Із відомих провідників першого десятиліття “Львівського Бояну” (А. Вахнянин, о. О. Нижанківський, Ф. Колесса, С. Людкевич та ин.), як виглядає з інформації у періодичній пресі, саме С. Федак часто поступався диригентським пультом своїм добре знаним на творчій ниві колегам-музикантам. Наприклад, Шевченківський концерт 1897 р. провадив о. О. Нижанківський (вже після свого вимушеного відходу 3

\footnotetext{
${ }^{40}$ Михайло Волошин, “Львівський Боян”, Альманах Музичний. Літературна часть першого ілюстрованого калєндаря музичного на рік 1904. Зложив і впорядкував Р. Зарицкий. (Львів, 1904), 105-111.

${ }^{41}$ Станіслав Людкевич, “У сорокліття «Львівського Бояна»” (1891-1931), Діло, ч. 51, (1932): 2.

42 “[Въ честь ХХХ-ыхъ роковынъ смерти Тараса Шевченка]”, Дкло, ч. 71, (1891): 1.
} 
ISSN 2078-6077. Наукові зошити історичного факультету Львівського університету. 2020. Випуск 21. Proceedings of History Faculty of Lviv University. 2020. Issue 21.

товариства через планований виїзд у США) $)^{43}$, у 1901 р. - С. Людкевич (того року заступник головного диригента). Цікаву звістку щодо діяльної участи С. Федака у підготові згаданого концерту 1901 р. знаходимо в "Руслані”: "При сій нагоді належить піднести заслугу дірігента “Льв. Б.” п. д-ра Федака, який немало задав собі труду, щоби приготовити хор до гідного виступу перед широкою публикою, аби міг заслужити на єї признання" 44 . Частково проливає світло на твердження рецензента той факт, що С. Людкевич (на цьому концерті вперше прозвучав його хор “Косар"45) 1901 р. як випускник Львівського університету, ймовірно, готувався до обов' язкових кваліфікаційних іспитів ${ }^{46}$.

Перший Шевченківський концерт за участю “Львівського Бояну” заслуговує особливої уваги і як вагома культурно-мистецька подія в національному житті галицьких українців, і як цікавий факт життєпису С. Федака. Концерт, приурочений до 30-річчя смерти Т. Шевченка, відбувся 14 квітня в залі Народного Дому. У програмі значилися: промова К. Левицького, “Молитва" і соло з опери “Купало" А. Вахнянина, полонез для фортепіяно, хорова поема "Гус", терцет 3 опери "Різдвяна ніч" М. Лисенка, декламація з "Гайдамаків" і “Посланія..." Т. Шевченка та "Заповіт” о. М. Вербицького ${ }^{47}$. Відтак, хор готував лише три твори: "Молитву” А. Вахнянина для мішаного хору, поему “Гус" М. Лисенка (для чоловічого хору) і “Заповіт” о. М. Вербицького (для подвійного, тобто восьмиголосного, хору зі солістом). Рецензент “Діла" твердить, що саме С. Федак керував хором на цьому концерті: “Сей першій выступъ “Львоิвского Бояна" бувъ дуже щасливый, а выконанье поодинокихъ п 中сенъ мусъло задовоิльнити й найбоิльше вымагаючого критика. Хоромъ управлявъ д-ръ Степанъ Федакъ, въ заступствъ недужого проф. Анатоля Вахнянина, и въ значно̂й мłpł праци та старанности д-ра С. Федака належить дякувати, що сы вечерниц' выпали такъ св'втло" (підкреслення наше - H. K.) ${ }^{48}$.

У літні місяці “Львівський Боян” влаштовував концертні (“артистичні”) мандрівки в різні містечка і села Галичини, підтримуючи традицію академічних гуртків (віденської “Січі” й “Академічного Братства”), а також збираючи в такий спосіб кошти на різноманітні суспільні потреби. У 1892 р. дві групи львівських “бояністів" подорожували по східних і західних теренах краю. Східна група під керівництвом В. Нижанківського концертувала переважно українськими повітами сучасної Львівщини, Івано-Франківщини та Тернопільщини (Любінь, Калуш, Трускавець, Дрогобич, Стрий, Золочів, Тернопіль, Броди, Сокаль, Жовква,

43 “[Въ память XXXVI-ыхъ роковынъ смерти Тараса Шевченка]”, Дълло, ч. 49, (1897): 3.

44 “Тарасові вечерниці у Львові”, Руслан, ч. 50, (1901): 3.

45 “Тарасові вечерниці у Львові”, Руслан, ч. 50, (1901): 3.

46 Зеновія Штундер, Станіслав Людкевич. Життя і творчість, у 2 т., Т. 1 (1879-1939). (Львів, 2005), 139.

47 “[Въ честь ХХХ-ыхъ роковынъ смерти Тараса Шевченка]”, Дқло, ч. 71, (1891): 3.

48 “[Вечеръ въ честь Тараса Шевченка]”, Дъкло, ч. 76, (1891): 1. 
Рогатин, Чортків, Коломия $)^{49}$, визначаючи своєю метою підносити національну свідомість галицьких українців. Західна група “Львівського Бояну”, якою керував о. О. Нижанківський, охопила не лише суто українські, але й польські терени, пропагуючи серед місцевих мешканців українську музичну культуру. С. Федак, разом із О. Колессою, А. Крушельницьким, Й. Дрималиком, С. Паньківським та ин., того року брав участь у мандрівках по західній частині Галичини за маршрутом: Самбір, Сянік, Івоничі, Риманів, Жегестів, Криниця, Щавниця, Новий Торг, Закопане, Тішинь та ин. ${ }^{50}$ У концертах групи, які відбувалися часто в місцевих санаторіях і супроводжувалися прийомами в маєтках польських магнатів, брала участь і С. Крушельницька. Про один 3 таких прийомів у гр. Потоцьких ${ }^{51}$ згадала й українська преса. На ньому С. Федак виголосив промову, пояснюючи мету утворення й діяльности українського хорового товариства “Львівський Боян”. У звіті “Діла” з тієї поїздки стверджувалося, що

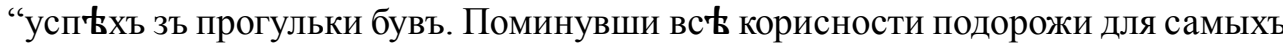
участникоिвъ ще головно розголосъ имени руского и голосна луна та тріюмфы національнои музыки - то нашы трофей" 52 .

Під керуванням С. Федака-диригента відбувалися концерти 1894, 18981901 pр., організовані самим товариством “Львівський Боян”, а частіше - спільно з іншими українськими установами. Шевченківський концерт 1894 р. заслуговує на увагу з огляду на участь в ньому знаменитих співаків С. Крушельницької та О. Мишуги, яким "поิднесли при ентузіястичныхъ оплескахъ публики голова "Бояна" п. Шухевичъ и дірігентъ д-ръ Федакъ лавровы в 'ннц' зъ воिдповоิдными написами на синьо-жовтыхъ лентахъ" ${ }^{\circ 3}$.

Однак вершинним для С. Федака став 1898 р. - рік кількох знаменних для українського відродження ювілеїв, зокрема 100-ліття публікації поеми “Енеїда" I. Котляревського та 50-ліття скасування в Галичині панщини. За цей рік “Львівський Боян” організував чи взяв участь у семи концертах (не враховуючи традиційних літніх мандрівок “шістнадцятки”, якими того року знову керував о. О. Нижанківський): концерт 3 метою збору коштів для спорудження пам'ятника М. Шашкевичеві (Львів, 1 лютого) ${ }^{54}$, концерт слов'янських пісень $(\text { (Львів, } 5 \text { березня) })^{55}$, шевченківський концерт (Львів, 4 квітня) $)^{56}$, 100-ліття

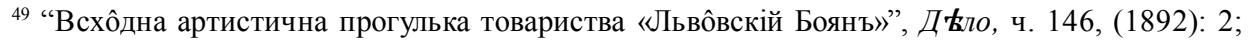
ч. $147,(1892): 2$.

50 “Артистична прогулька «Львоิвского Бояна» [въ захоิдну часть Галичины и на Шлескъ]”, Дъло, ч. 140, (1892): 3.

${ }^{51}$ К. “Захоิдна прогулька «Јьвоิвского Бояна»”, Д

52 “Справозданье изъ захоิднои артистичнои прогульки спһвацкого товариства «Львоิвскій Боянъ»”, Дъло, ч. 221 (1892): 2.

53 "Шевченкове свято у Львовъ", Д Дло, ч. 101 (1894): 2.

54 “[Концерть устроеный д. 1 н. ст. лютого]”, Д қло, ч. 17, (1898) : 3.

55 “[Програма славяньского концерту «Львоิвского Бояна»]”, Д

56 "[Програма концерту въ память XXXVII-ыхъ роковинъ смерти Тараса Шевченка]", Д ч. $63,(1898): 3$.
} 
ISSN 2078-6077. Наукові зошити історичного факультету Львівського університету. 2020. Випуск 21. Proceedings of History Faculty of Lviv University. 2020. Issue 21.

української літератури (Стрий, 28 квітня) ${ }^{57}, 50$-ліття скасування панщини у Галичині (Львів, травень) ${ }^{58}$, концерт С. Крушельницької (Львів, 21 червня) ${ }^{59}$, 100-ліття української літератури (Львів, 31 жовтня) ${ }^{60}$. Вражає не лише те, що у весняно-літній сезон концерти відбувалися щомісяця - очевидно, вперше від часу утворення "Бояна", але й різноманітність виконуваних творів. Попри деякі організаційні труднощі - наприклад, вказувалося на слабший, ніж в інші роки, добір голосів хору, та величезне навантаження С. Федака в інших сферах громадського життя, рецензенти завжди віддавали належне його працездатності і відповідальності як диригента. Ось як відгукнулося “Діло” на співучасть "Львівського Бояну" в концерті С. Крушельницької: "Хор “Львоิвского Бояна" выконавъ ще Лисенка "Скорбны думы" та Малята "Пьсни люду ческого" и заслуживъ собъ на загальну хвалу воิдъ публики. Се заслуга невтомимо трудящого д-ра. Ст. Федака, дирігента хору, котрый мимо великихъ занять свого званя посвячує воิльный часъ вышколеню сего хору и дов розцвьту" 1 .

Із напруженого концертного сезону 1898 р. заслуговують на окрему згадку дві мистецькі події. Перша - концерт слов'янських пісень, який став першою спробою “Львівського Бояна" організувати власний музично-тематичний вечір. Дописувач “Діла” підкреслював, що концертну програму члени хорового товариства добирали і готували понад рік ${ }^{62}$, зокрема велика заслуга в тому належала голові товариства В Шухевичу та, ймовірно, С. Федакові, який, з огляду на обов'язки головного диригента, визначав репертуар. На концерті “Боян” виконував обробки народних пісень й авторські хорові твори - українських, польських, чеських, російських, болгарських, сербо-хорватських, словенських композиторів.

Друга вагома подія того року - столітній ювілей відродження української літератури (вихід у світ “Енеїди” І. Котляревського) - по суті переросла у національно-культурну маніфестацію. Урочистості тривали два дні, головною музичною подією на них став великий концерт у Театрі Скарбка 31 жовтня за участю “Боянів” зі Львова, Стрия, Перемишля і Коломиї. До програми того концерту залучено: 1) Драматичний пролог у двох відмінах I. Франка (декламація); 2) кантату “На вічну пам'ять Котляревському”о. Й. Кишакевича; 3) "Наталку Полтавку” І. Котляревського (у виконанні акторів театру “Руська Бесіда”) 4) “Вечорниці” П. Ніщинського; 5) симфонію g-moll М. Вербицького.

57 “Торжество століття украиньско-рускои словесности въ Стрыю”, Дъло, ч. 87, (1898) : 1.

58 “Програма вечерниць устроюваныхъ у Львовћ въ 50-ты роковины Знесеня панщины”, Дъло, ч. 97, (1898): 2.

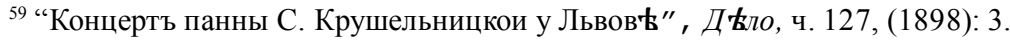

60 “Свято сотныхъ роковинъ воิдродженя руского письменьства”, Дкло, ч. 235, (1898): 1-2.

61 “Концерть панны С. Крушельницкои у Львовъ”, Д

62 “[Товариство «Львоิвскій Боянъ»]”, Д 
С. Федак диригував об” єднаним хором “Боянів” у супроводі оркестри, виконуючи "Вечорниці” П. Ніщинського. Піднесену атмосферу цього святкування, яку підтримував і спів хору, добре передає спогад рецензента: “Хто бувъ на тоิмъ святочноิмъ вечерt въ театр' не забуде до в по коิнцевыхъ словахъ прольогу “Ще не вмерла, ще не вмерла и не вмре!" залунавъ въ театр† “єдинымъ серцемъ и єдиными устами” урочистий гимнъ "Ще не вмерла Украина", — якъ зновъ опоิсля поิднялась занав Һса и явивъ ся на сцен中 величавый хоръ сполученыхъ “Бояноิвъ” зложеный зъ якихъ 150 осоิбъ $[\ldots]^{\prime \prime 33}$.

Із концертів наступних років виділяється ювілей 10-ліття утворення “Львівського Бояна" (червень 1901 р.), який став своєрідною ретроспективою національної музичної творчости XIX ст. і мистецької діяльности товариства, презентуючи кращі зразки української хоровою літератури з його репертуару: композиції Д. Бортнянського, о. М. Вербицького, о. І. Лаврівського, о. С. Воробкевича, А. Вахнянина, о. О. Нижанківського, Д. Січинського, о. Й. Кишакевича, Ф. Колесси, о. В. Матюка, С. Людкевича, П. Ніщинського, М. Лисенка - орієнтовно 17 творів $^{64}$. Мистецький провід концерту - чотири чільні диригенти “Львівськкого Бояну”: о. О. Нижанківський, Ф. Колесса, С. Людкевич i С. Федак. Цікаво, що рецензент “Діла”, об'єктивно і критично оцінюючи виконання хором окремих композицій, відзначив індивідуальність і різні темпераменти диригентів ${ }^{65}$. У дописі про цей ювілей, поданий у “Руслані", вказано ще і який саме твір диригував С. Федак: "Концерт закінчив ся звісною вже всім нам ораториєю Лисенка “Б’ють пороги”, під управою д-ра Федака. Діригенти поодиноких нумерів, пп. Ніжанковский, Людкевич, др Федак і Колесса вивязали ся з своїх задач совісно, а члени "Бояна" - знаменито"б6.

Матеріяли преси - програми концертів і рецензії, дозволяють лише орієнтовно й неповністю відтворити репертуар С. Федака як диригента. Добірка творів дуже характеристична для раннього етапу діяльности “Бояна", адже провідне місце у ній посідають хори галицьких композиторів XIX ст. (о. М. Вербицького, о. І. Лаврівського, А. Вахнянина, Д. Січинського тощо) та М. Лисенка, серед них і такі великосяжні та доволі складні полотна як “Заповіт” М. Вербицького та кантата “Б”ють пороги” М. Лисенка, якими С. Федак, ймовірно, диригував неодноразово, значна кількість хорових обробок народних пісень.

У дописах періодичної преси збереглася інформація і про два, ймовірно, останні диригентські виступи С. Федака в урочистостях 20-30-х pp. ХX ст. 3 нагоди 100-ліття утворення Перемишльського катедрального хору 1929 р. у Перемишлі

63 “Свято сотныхъ роковинъ воิдродженя руского письменьства”, Д

64 “Ювилейний концерт «Јьвівського Бояна»”, Руслан, ч. 136, (1901): 3. Точно програму відтворити не вдалося, оскільки рецензенти “Діла” і “Руслана” не перераховували всіх виконаних композицій.

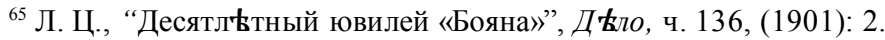

66 “Замітки $з$ нагоди ювилейного концерту «Јьвівського Бояна»”, Руслан, ч. 140, (1901): 2. 
ISSN 2078-6077. Наукові зошити історичного факультету Львівського університету. 2020. Випуск 21. Proceedings of History Faculty of Lviv University. 2020. Issue 21.

(27 травня) та Львові (2 червня) відбувся великий фестиваль за участю провідних українських хорів - "Боянів" зі Львова, Перемишля і Стрия, чоловічого хору товариства "Просвіта" “Сурма", академічного хору "Бандурист" і хору богословів. Програму фестивалю уклали в такий спосіб, щоб відтворити історичний шлях формування українських галицьких хорів. Звучали духовні і світські твори композиторів XIX - початку XX ст. від Д. Бортнянського до сучасности, на сцену почергово виходили найвідоміші диригенти С. Людкевич, I. Охримович, М. Волошин, о. В. Садовський, а також С. Федак. Рецензент "Діла" із щирою повагою написав про диригентський вихід С. Федака $\mathrm{i}$ О. В. Садовського - ветеранів хорового руху в Галичині на львівському концерті фестивалю: "На першу часть програми припали церковні твори Вербицького, Лаврівського і Бортнянського, диріговані по черзі д-ром Федаком, о. Садовським, I. Охримович і д-ром С. Людкевичем.[...] В виведенні д-ра Федака і о. Садовського ближчих до церковних традицій і багатших в пієтизм, зискали ці твори на стилю, і поставили відразу настрій концерту на відповідний рівень. Видно було в цих дирігентів руку досвідних і обізнаних з хором, і приходиться лише жаліти, що так рідко появляються вони на концертовій естраді”"67.

Як диригент С. Федак був запрошений і 1932 р. на концерт з нагоди 40-ліття утворення “Львівського Бояну”. На цей раз поруч із ним були С. Людкевич, М. Колесса (диригенти “Бояну”) та І. Охримович (“Сурма”). 3 відгуку композитора і музикознавця Б. Кудрика відомо, що у виконанні “Львівського Бояна” під керуванням С. Федака прозвучала композиція Д. Січинського “Дніпро реве": "Першої точки - мішаного хору Січинського “Дніпро реве” з барітоновим солом (проф. Прокопович-Орленко ${ }^{68}$ ) і достроєм фортепяну - вислухала саля 3 особливим пієтизмом, як реліквії давніх добрих часів. Цього милого спогадового настрою додавала щей особа диригента, д-ра Степана Федака, одного 3 тих дорогих, а вже дуже нечисленних ветеранів нашого співочого світа" 69 .

Майже не відомою залишається очевидна матеріяльна допомога С. Федака музичним товариствам. Однак у документах Музичного товариства ім. М. Лисенка зафіксовано такий промовистий факт: “В серпні 1915, почали вертати члени Виділу (Музичного товариства ім. М. Лисенка - H. К.) і на засіданю дня 11 вересня 1915, рішено відчинити знова музичну школу (Вищий Музичний Інститут ім. М. Лисенка $-H$. K.) і продовжати будову дому (будинок при вул. Шашкевича $-H$. К.). Школу було відкрито і ведено єю через 2 місяці в новім будинку, а для браку інсталяцій елєктрично-каліориферових, рішено перепровадити ся на зиму до камяниці директора Д-ра Федака, з відки повернено

\footnotetext{
${ }^{67}$ I. О-вич, “3 концертової салі. Концерт з нагоди 100-літніх роковин оснування першого хору на Галицькій Землі в Перемишлі”, Діло, ч. 124, (1929): 5.

${ }^{68}$ Роман Прокопович-Орленко (1883-1962) - знаменитий український оперний співак (басбаритон), педагог і диригент, соліст Фольксопери у Відні, соліст і актор театру “Української Бесіди".

${ }^{69}$ Борис Кудрик, “Концерт з нагоди 40-ліття «Львівського Бояна»”, Діло, ч. 58, (1932): 3.
} 
до нового будинку доперва 1 мая 1916"ㄱ․ Отже, під час Першої світової війни у кількох кімнатах із помешкання С. Федака Вищий Музичний Інститут (BMI) ім. М. Лисенка працював понад півроку ${ }^{71}$. Цей випадок засвідчує шляхетну $\mathrm{i}$ благородну поставу д-ра С. Федака.

Об'єктивно характеризуючи мистецькі здобутки українських галицьких композиторів і музикантів-аматорів XIX ст. та їх внесок у розвиток національної культури, з нагоди 100-ліття утворення Перемишльського катедрального хору, визначний український композитор і довголітній директор ВМІ ім. М. Лисенка у Львові (згодом, Львівської Державної Консерваторії) В. Барвінський писав: “Хоча з нинішньої перспективи вільно нам підходити до тих початків нашого галицького музичного мистецтва із здоровим критицизмом, то з другої сторони не вільно нам ніяк ставитися до них з легковажанням. Тому кожна наша тямуча людина повинна бачити в тих починах наших предків хоч би нині вже скромні, то в тодішніх часах незвичайно цінні цеголки, з яких починалася будова нашого музичного мистецтва в Галичині"’72. Діяльність цієї музичної генерації, до якої належав і С. Федак - один із найшанованіших та найповажаніших у Галичині провідників і диригентів “Львівського Бояна", сформувала організаційні та мистецькі підстави для розвитку професіоналізму в музичній культурі, визначила iï націотворчі та естетичні цілі, розкрила можливості поступу українців у сфері творчости.

Навіть цей короткий огляд музично-диригентської діяльности С. Федака розкриває типові погляди галицько-української інтелігенції щодо розвитку національної культури, а саме - вагомої ролі окремих їі сфер, зокрема музики, в піднесенні самосвідомости українців, поступі їх духовного і суспільного життя. Тим самим підтверджується, що ця активність в організаційній, концертновиконавській, зокрема і диригентській ділянці, сформувала потужний пласт українського музичного аматорства в Галичині першої половини XX ст., закладаючи тривкі основи мистецького і суспільно-культурного розвитку українців загалом.

\footnotetext{
${ }^{70}$ 3віт з будови власного дому Муз. Товариства ім. Миколи Лисенка зладжений на загальні збори Товариства дня 26 мая 1917. (Львів: Накладом Муз. Товариства, [1917]), 4.

${ }^{71}$ Йдеться про помешкання за адресою вул. Сикстустська (зараз вул. П. Дорошенка), 48, де BMI ім. Миколи Лисенка винаймав три кімнати і кухню. Див. Книга протоколів музичного товариства імені Миколи Лисенка, упор. і вступна стаття Якима Горака. (Тернопіль, 2014), 53.
} 
ISSN 2078-6077. Наукові зошити історичного факультету Львівського університету. 2020. Випуск 21. Proceedings of History Faculty of Lviv University. 2020. Issue 21.

\title{
STEPAN FEDAK: THE FEATURES OF THE PROFILE
}

\author{
Nataliia KOBRYN \\ Lviv Secondary Specialized Music Boarding School \\ named by Solomiia Krushelnytska \\ Zelena str., 79005, Lviv, Ukraine \\ e-mail: kobryn.natalya@gmail.com
}

Stepan Fedak (1861-1937) was a well-known Ukrainian lawyer and one of the first conductors of the "Lviv Boian" choral society in the first half of the 20th centry. He was accepted with high esteem by his contemporaries, among whom was the illustrious Ukrainian composer and music critic Stanislav Liudkevych, for the contribution to the national music culture of Ukraine.

S. Fedak, the artist was formed in Lviv's amateur music circles in late 19th century - in the concerts and educational practices of numerous choirs in schools and seminaries, in the music sections of the Ukranian "Prosvita" ("Enlightment") society, as well as other musical organizations, such as the Halychyna Musical Society, the Polish choral society "Lutnia" ("Lute") and the Ukrainian choir society "Torban". Over the years of his involvement in "Lviv Boian" S. Fedak was a chorister, one of the choir's principal conductors (in 1894, 1896-1901) and vice-chaiman of the society (in 1891-1896). He was a co-founder of "Boyan Association" (an association of "Boyan" Ukranian choirs) and "The Union of Ukranian Singers and Musical Societies" (founded in 1903). S. Fedak also was the member of the committee of the Mykola Lysenko Musical Society charged with overseeing the construction of the society's headquarters (now it is Stanislav Liudkevych State Musical College in L'viv, on 5 Markiyan Shashkevych Street).

Following a review of Ukrainian periodicals from that era, in particular the dailies "Dilo" and "Ruslan," the author of this paper has analyzed the information related to the concerts and works performed by "Lviv Boian" when conducted by Lviv Boian.

Keywords: music culture of Ukrainians of Galicia, "Lviv Boian”, concerts, conductor, Stepan Fedak.

\section{REFERENCES}

Artystychna prohul'ka Lvivskoho Boiana (u Zakhidnu chastynu Halychyny i na Lishle (Śląsk), Dilo, No. 140 (1892): 3 (in Ukrainian)

Barvinsky, Vasyl. Sviato 100-litnikh rokovyn zasnuvannia pershoho mystetskoho khoru na Halytskiy Ukraini pry soborniy tserkvi u Peremyshli, Dilo, No. 119 (1929): 5 (in Ukranian) Berezhnytsky, Oles. Nashi muzyky, Artystychny Vistnyk, No. 9/10, (1905): 124 (in Ukrainian) Dr Stepan Fedak, Dilo, No. 6, (1937): 3 (in Ukrainian)

Fedak, Stepan, Shukhevych Volodymyr, Vidozva i zaprosyny do spivolubyvykh rusyniv, Dilo, No. 221, (1896): 3 (in Ukrainian)

I. O-vych. Z kontsertovoii zali. Kontsert z nahody osnuvannia pershoho khoru na Halytskii Zemli v Peremyshli, Dilo, No. 124, (1929): 5 (in Ukrainian)

Khanyk, Lidia. Istoriia khorovoho tovarystva “Lvivskyi Boian”. (Lviv, 1999), 122 (in Ukrainian) Knyha protokoliv muzychnoho tovarystva imeni Mykoly Lysenka, upor I vstupna stattia Yakyma Horaka. (Ternopil, 2014), 424.

Kobryn, Nataliia, "Muzyka yak skladova hromads'koi pratsi halytskykh Ukraintsiv na mezhi XIX - XX st. (na prykladi dijzl'nosti Andria Chajkovs'koho)". Vyznachni postati Ukrainy: Andrii Chaikovskyi ta Teofil Okunevskyi": Zbirnyk naukovykh prats, prysviachenykh 150-richchiu vid dnia narodzhennia Andriia Chaikovskoho (2007) ta Teofila Okunevskoho (2008), hol. red ta upor. B. Yakymovych za uchastiu N. Kobryn, V. i R. Melnykiv, O. Sedliara. (Lviv, 2010), 78-84 (in Ukrainian) 
Kontsert panny S. Krushelnytskoii u Lvovi, Dilo, No. 127, (1898), 3 (in Ukrainian)

Kontsert ustroienyi dnia 1 liutoho, Dilo, No. 17, (1898): 3 (in Ukrainian)

Kudryk, Borys. Kontsert z nahody 40-littia "Lvivskoho Boiana”, Dilo, No. 58, (1932): 3-4 (in Ukrainian)

Kudryk, Borys. Ohliad Ukrainskoii tserkovnoii muzyky, (L’viv, 1995), 128 (in Ukrainian)

K. Zakhidna prohulka "Lvivskoho Boiana", Dilo, No. 167, (1892): 3 (in Ukrainian)

Liudkevych, Stanislav. Nashi spivaky i narodna sprava, Doslidzhennia, statti, retsenzii, vystupy, u 2 t, t. 2, upor. Z. Shtunder, (Lviv, 2000) pp. 352-356 (in Ukrainian)

Liudkevych, Stanislav. U soroklittia "Lvivskoho Boiana", Dilo [Work], No. 52, (1933): 2 (in Ukrainian)

Lysko, Zynovii. Pionery Ukrainskoho muzychnoho mystetstva v Halychyni, upor. V. Syvohip, (Lviv, Niu-York, 1994), 144 (in Ukranian)

L.Ts. Desiatlitnii yuvilei "Boiana", Dilo, No. 136, (1901): 2 (in Ukrainian)

Mazepa, Leshek, Mazepa, Tereza. Shliakh do Muzychnoi Akademii u Lvovi, u 2 t., t. 1: (Vid doby miskykh muzykantiv do Konservatorii [poch. XV st - do 1939 r.]. (Lviv, 2003), 288 (in Ukrainian)

M. B. [Lviv Boian], Dilo, No. 2, (1901): 2-3 (in Ukrainian)

[Ostap Nyzhankyvskyi], Dilo, No. 139, (1896): 1-2 (in Ukrainian)

Pershi zahalni zbory rus'koho spivnoho Tovarystva "Boian", Dilo, No. 20, (1891): 3 (in Ukrainian)

Prohrama kontsertu v pamiat XXXVII-kh rokovyn smerty Tarasa Shevchenka, Dilo, No. 63, (1898): 3 (in Ukrainian)

Prohrama Slov'ianskoho kontsertu "Lvivskoho Boiana", Dilo, No. 39, (1898): 3 (in Ukrainian)

Prohrama vechernyts ustroiuvanykh u Lvovi v 50-ti rokovyny znesennia Panshchyny, Dilo, No. 97, (1898): 2 (in Ukrainian)

Rukh v Rus'kykh tovarystvakh, Dilo, No. 254, (1894): 2 (in Ukrainian)

Rukh v Rus'kykh tovarystvakh (Zahalni zbory tov. "Lvivs'kyi Boian"), Dilo, No. 260, (1896): 3 (in Ukrainian)

Rukh v Ruskykh tovarystvakh. Z'iizd Boianiv, Dilo, No. 260/261, (1901): 3 (in Ukrainian)

Skhidna artystychna prohulka tovarystva "Lvivskyi Boian", Dilo, No. 146, (1892): 2, No 147, (1892): 2 (in Ukrainian)

Shevchenkove sviato u Lvovi, Dilo, No. 101, (1894): 2 (in Ukrainian)

Shtunder, Zenoviia. Stanislav Liudkevych: Zhyttia i tvorchost, u 2 tomakh, t. 1 (1979-1939). (Lviv, 2005), 636 (in Ukrainian)

Shukhevych, Taras. Chy muzychne vykhovannia molodi potribne? Dilo, No. 312, (1934): 2 (in Ukrainian)

Sprava pro orhanizatsiiu muzychnoho tovarystva $u$ Lvovi, Tsentralnyi derzhavnyi istorychnyi arkhiv Ukrainy u Lvovi, f. 146, op. 4, spr. 665, p 21 (in Ukrainian)

Spravozdannie iz Zakhidnoi artystychnoi prohul'ky spivats'koho tovarystva "Lvivskyi Boian”, Dilo, No. 221, (1892): 2 (in Ukrainian)

Statuty tovarystv Halychyny. Tsentralnyi derzhavnyi istorychnyi arkhiv Ukrainy u Lvovi, f. 362, op. 1, spr. 196, p 18 (in Ukrainian)

Svyato sotnykh rokovyn vidrodzhennia rus'koho pysmenstva, Dilo, No. 235, (1898): 1-2 (in Ukrainian)

Tarasovi vechornytsi u Lvovi, Ruslan, No. 50, (1901): 3 (in Ukrainian)

Ti, shcho vid nas vidiyshly [dr Stepan Fedak], Zhyttia i Znannia, No. 2(113), (1937), 64 (in Ukrainian) 
ISSN 2078-6077. Наукові зошити історичного факультету Львівського університету. 2020. Випуск 21. Proceedings of History Faculty of Lviv University. 2020. Issue 21.

Tovarystvo “Lvivskyi Boian”, Dilo, No. 38, (1898): 3 (in Ukrainian)

Torzhestvo stolittia Ukrainsko-rus'koi slovesnosti v Stryiu, Dilo, No. 87, (1898), 1 (in Ukrainian) Ustav Muzychnoho tovarystva imeni Mykoly Lysenka, trettie vydannia, (Lviv, 1921), 2. Natsionalna naukova biblioteka imeni Vasylia Stefanyka, viddil rukopysiv, f. 163, p. 50, 36 (in Ukrainian)

V chest XXX-kh rokovyn smerty Tarasa Shevchenka, Dilo, No. 71, (1891): 1 (in Ukrainian)

Vecher v chest Tarasa Shevchenka, Dilo, No. 76, (1891): 1 (in Ukranian)

Volodymyr Shukhevych: Biobibliografichnyi pokazhchyk u 2 t., upor. M. Hodiy, B. Helyas, peredmova R. Kyrchiv, (Lviv, 2004), 90.

Voloshyn, Mykhaylo. Lviv Boian. Musychnyi almanakh, Literaturna chast pershoho musychnoho kalendaria na rik 1904, upor. R. Zarytskyi, (Lviv, 1904), 105-111 (in Ukrainian)

V pamiat XXXVI-kh rokovyn smerty Tarasa Shevchenka, Dilo, No. 49, (1897): 3 (in Ukrainian)

Vytvytskyi, Vasyl. Stolitt'a urodyn dvokh ukrainskykh muzyk (Pamiati P. Bazhanskoho i S. Vorobkevycha), Novyi Chas, No. 105, (1936), 2 (in Ukrainian)

Yuvileini zahalni zbory tovarystva "Prosvita", Dilo, No. 17, (1894), 1 (in Ukrainian)

Yuvileinyi kontsert “Lvivskoho Boiana”, Ruslan, No. 136, (1901), 3 (in Ukrainian)

Zahalni zbory "Lvivskoho Boiana”, Dilo, No. 102, (1894), 2 (in Ukrainian)

Zamitky z nahody yuvileinoho kontsertu "Lvivskoho Boiana", Ruslan, No. 140, (1901), 2 (in Ukrainian)

Z "Lvivskoho Boiana”, Dilo, No. 260/261, (1901), 3 (in Ukrainian)

Zvit z budovy vlasnoho domu Muz. Tovarystva im. Mykoly Lysenka zladzheny na zahal'ni zbory Tovarystva dn'a 26 mayz 1917, May26. (Lviv, printed by Music Society, 1917), 4 (in Ukrainian)

Zvit z diialnosti HMT za 1865 r., Derzhavnyi arkhiv Lvivskoii oblasti, f. 3, op. 1, spr. 2384 (in Ukrainian) 